UDC 339.186.001.3.2

DOI: https://doi.org/10.32840/1814-1161/2021-1-12

\author{
Naumenko Mariya \\ Doctor of Philosophy in Economics, \\ Professor of Department of Management and the Military Economy \\ National Academy of the National Guard of Ukraine
}

Науменко М.O.

доктор фрілософії економічного напряму, профресор кафедри менеджменту та військового господарства Національної академії Національної гвардії України

\title{
ORGANIZATION OF PROCUREMENT OF GOODS, WORKS AND SERVICES FOR UNITS OF THE NATIONAL GUARD OF UKRAINE
}

\section{ОРГАНІЗАЦІЯ ЗАКУПІВЕЛЬ ТОВАРІВ, РОБІТ ТА ПОСЛУГ ДЛЯ ПІДРОЗДІЛІВ НАЦІОНАЛЬНОЇ ГВАРДІЇ УКРАЇНИ}

This article presents a method of making management decisions on the organization of procurement of goods, works and services for units of the National Guard of Ukraine. The analysis of characteristic features of the modern market environment of realization of tender purchases is carried out. The specifics of the customer-oriented approach to the organization of the tender procurement system are considered. The article substantiates the need to use a customer-oriented approach to create a methodology for making management decisions on the organization of procurement, which is due to the high level of competition between different organizations, making it difficult to stand out by improving the quality of goods and services. The process of evolution of economic paradigms, as a result of which there is an urgent need for the organization of effective management of relations with clients is analyzed. The economic-mathematical model of decision support on positioning of the organization in the market of tender purchases is offered. The formulas of calculation of key indicators which will allow to carry out positioning of the organization in the market of tender purchases are offered. Such indicators are the intensity of interaction with customers and the level of technological equipment of the organization. The intensity of interaction with consumers in the work is proposed to be expressed in units of frequency and amounts of orders for goods and services. The indicator of the level of technological equipment of the organization is calculated taking into account the number of technological innovations of the organization for a certain period of time. The hypothesis of the research was the assumption that a positive change in one of the proposed indicators results in a corresponding positive shift in the second indicator. The scheme of positioning of the organization in the market of tender purchases in the article it is offered to consider a matrix of the preliminary estimation of possibilities of the organization in the market of tender purchases. As a result of the analysis of the matrix quadrants, a set of recommendations to the enterprise management system regarding the organization of procurement of goods, works and services for units of the National Guard of Ukraine was formed.

Keywords: methodology, procurement, organization, military units, customer-oriented approach.

У даній статті подано методику прийняття управлінських рішень щодо організації закупівель товарів, робіт та послуг для підрозділів Національної гвардії України. Проведено аналіз характерних особливостей сучасного ринкового середовища здійснення тендерних закупівель. Розглянуто специфріку клієнтоорієнтованого підходу стосовно організації системи тендерних закупівель. В статті обгрунтовано необхідність використання клієнтоорієнтованого підходу для створення методики прийняття управлінських рішень щодо організації закупівель, яка обумовлюється високим рівнем конкуренції між різними організаціями, внаслідок чого важко виділитися за рахунок підвищення якості товарів і послуг. Проаналізовано процес еволюції економічних парадигм, внаслідок якої виникає нагальна потреба організації ефрективного управління взаємовідносинами з клієнтами. Запропонована економіко-математична модель підтримки прийняття рішень щодо позиціонування організації на ринку тендерних закупівель. Запропоновано формули розрахунку ключових показників, які дозволять здійснювати позиціонування організації на ринку тендерних закупівель. В якості таких показників виступають інтенсивність взаємодії з замовниками продукції та рівень технологічної оснащеності організації. Інтенсивність взаємодії зі споживачами в роботі пропонується виражати в одинииях частоти і сумах замовлень товарів і послуг. Показник рівня технологічної оснащеності організації розраховується з урахуванням кількості технологічних новацій організації за певний проміжок часу. Гіпотезою проведеного наукового дослідження стало припущення, що позитивна зміна одного з за- 
пропонованих показників має наслідком відповідне позитивне зрушення другого показника. Схемою позиціонування організації на ринку тендерних закупівель в статmі пропонується вважати матрицю попередньої оцінки можливостей організації на ринку тендерних закупівель. В результаті аналізу квадрантів матриці сфрормовано комплекс рекомендацій системі менеджменту підприємства стосовно організації закупівель товарів, робіт та послуг для підрозділів Національної гвардії України.

Ключові слова: методика, закупівлі, організація, військові підрозділи, клієнтоорієнтований підхід.

В данной статье представлена методика принятия управленческих решений по организации закупок товаров, работ и услуг для подразделений Национальной гвардии Украины. Проведен анализ характерных особенностей современной рыночной среды осуществления тендерных закупок. Рассмотрена специфрика клиентоориентированного подхода по организации системы тендерных закупок. В статье обоснована необходимость использования клиентоориентированного подхода для создания методики принятия управленческих решений по организации закупок, которая обуславливается высоким уровнем конкуренции между различными организациями, в результате чего трудно выделиться за счет повышения качества товаров и услуг. Проанализирован процесс эволюции экономических парадигм, в результате которой возникает насущная необходимость организации эффрективного управления взаимоотношениями с клиентами. Предложенная экономико-математическая модель поддержки принятия решений относительно позиционирования организации на рынке тендерных закупок. Предложено фрормулы расчета ключевых показателей, которые позволят осуществлять позиционирование организации на рынке тендерных закупок. В качестве таких показателей выступают интенсивность взаимодействия с заказчиками продукции и уровень технологической оснащенности организации. Интенсивность взаимодействия с потребителями в работе предлагается выражать в единицах частоты и суммах заказов товаров и услуг. Показатель уровня технологической оснащенности организации рассчитывается с учетом количества технологических новаций организации за определенный промежуток времени. Гипотезой проведенного научного исследования стало предположение, что положительное изменение одного из предложенных показателей влечет соответствующий положительный сдвиг второго показателя. В качестве схемы позиционирования организации на рынке тендерных закупок в статье предлагается считать матрицу предварительной оценки возможностей организации на рынке тендерных закупок. В результате анализа квадрантов матрицы сформирован комплекс рекомендаций системе менеджмента предприятия по организации закупок товаров, работ и услуг для подразделений Национальной гвардии Украины.

Ключевые слова: методика, закупки, организация, воинские подразделения, клиентоориентированный подход.

Formulation of the problem. In order to ensure compliance with the conditions of transparency and in order to prevent corruption risks, military units of the National Guard of Ukraine should conduct tender procurement to meet the current needs of logistics. From the point of view of an organization that offers its goods and services to military units, in these conditions, the priority is to ensure its competitiveness. In turn, to ensure the competitiveness of the organization, it is important to agree on the procedure of interaction of the organization with military units as potential customers of goods and services.

The process of coordination of product parameters between the customer and the company is very timeconsuming, multifaceted, requires, due to its complexity, the availability of appropriate methodological support.

Analysis of recent research and publications. S. Sokolovskyi, O. Ryha in [1-3] the peculiarities of procurement management in the post-industrial economy are analyzed. X. Wan, M. Dresner, V. Fedorchenko is proposes analysis of the mechanisms of optimization of information systems for their further implementation in the management of procurement processes [4-6]. Scientific articles [7-9] by authors Y. Hrabovskyi, N. Brynza, O. Vilkhivska of are devoted to the consideration of web-based production management systems and the peculiarities of their use in specific practical areas of procurement processes.

Selection of previously unsolved parts of the overall problem. However, today in the specialized literature there is no methodological approach, which would contain a justification for the methodology of procurement of goods, works and services for units of the National Guard of Ukraine.

Formulation of the goals of the article (task statement). The purpose of the article is to create and scientifically substantiate the methodology of management decisions on the organization of procurement of goods, works and services for units of the National Guard of Ukraine.

Presentation of the main research material. The basic principles of effective interaction of the organization with military units of the National Guard of Ukraine in the conditions of tender procurement are based on ensuring customer orientation.

Ensuring the rational conduct of tender procurement of quality products requires a regulatory mechanism based on the legislation of Ukraine and standards of product standardization.

The modern market is characterized by the highest competition. It is very difficult to stand out by improving the quality of goods and services, because this path is usually associated with a significant increase in production costs, rising prices, which can lead to the opposite effect - the loss of customers.

In terms of market relations, the success of an organization that offers its products to military units of the National Guard of Ukraine (NGU) directly depends on the degree of demand for its product. A distinctive feature of the service is that it is produced and consumed simultaneously, which determines the high importance of the organization's focus on maximum customer 
satisfaction, in our case the military unit of the NGU. This property of the organization is called customer orientation [5].

In economic practice, there are three approaches to the organization of enterprise management: customeroriented, marketing-oriented and industry-oriented. The evolution of economic paradigms is presented in Figure 1.

The last decade of the 20th century. was marked by the formation of a customer-centered approach, the purpose of which was to build individual relationships with each of the company's customers.

The essence of the approach can be reduced to three main characteristics:

1) focus on customer retention. As increasing market share and attracting new customers is becoming more expensive for the company, it has become more profitable for the company to use the potential of the existing customer base and ensure sales growth by increasing the intensity of consumption of its products by existing customers;

2) individual communications with customers. To take into account the personal characteristics of each consumer, it is necessary to provide personal interactive interaction between him and the company. As a result of the development of information technologies, the solution of this issue has become possible;

3) cooperation based on relationships, not on product. As goods and services became more uniform, the basis for maintaining and developing cooperation between the company and its customers was the relationship (service).

The emergence of a customer-centered approach has complemented the set of organizational management functions of customer relationship management. Public production and marketing technologies can no longer provide the company with long-term leadership, they are necessary but insufficient. Now it is important not only to create a product and find customers who feel a real need for it, but also to focus the business on strengthening cooperation with more valuable consumers.

Today, the concept of product quality is increasingly becoming subjective and is formed in the processes of interaction between producer and consumer. The level of quality is determined by the degree of conformity of the characteristics of the product to the set of requirements put forward by the consumer. The most important aspect for enterprises is the fullest satisfaction of consumer requirements and expectations, ie the implementation of a customer-oriented approach.

Customer orientation is a strategic approach to the development of the organization, which increases its competitiveness and profitability, mobilization of all its resources to identify, attract customers and retain the most profitable of them, by improving customer service and meeting their needs. In conditions of fierce competition in the market of domestic and foreign organizations, only companies with the main competitive advantage - high quality management - can survive.

Improving the competitiveness of the company the market orientation of the company, focused on the study of customer needs as opposed to concentration on the product and effective sales, which meets the trends and rules of today's market.

Reducing the company's costs - the study of customer behavior and preferences in order to increase the level of retention and satisfaction of the most profitable of them, while identifying low-income customers.

Adherence to the balance of company interests and customer satisfaction. Based on the study of consumer demand and preferences, the behavior of competitors, the company offers different programs to its customers

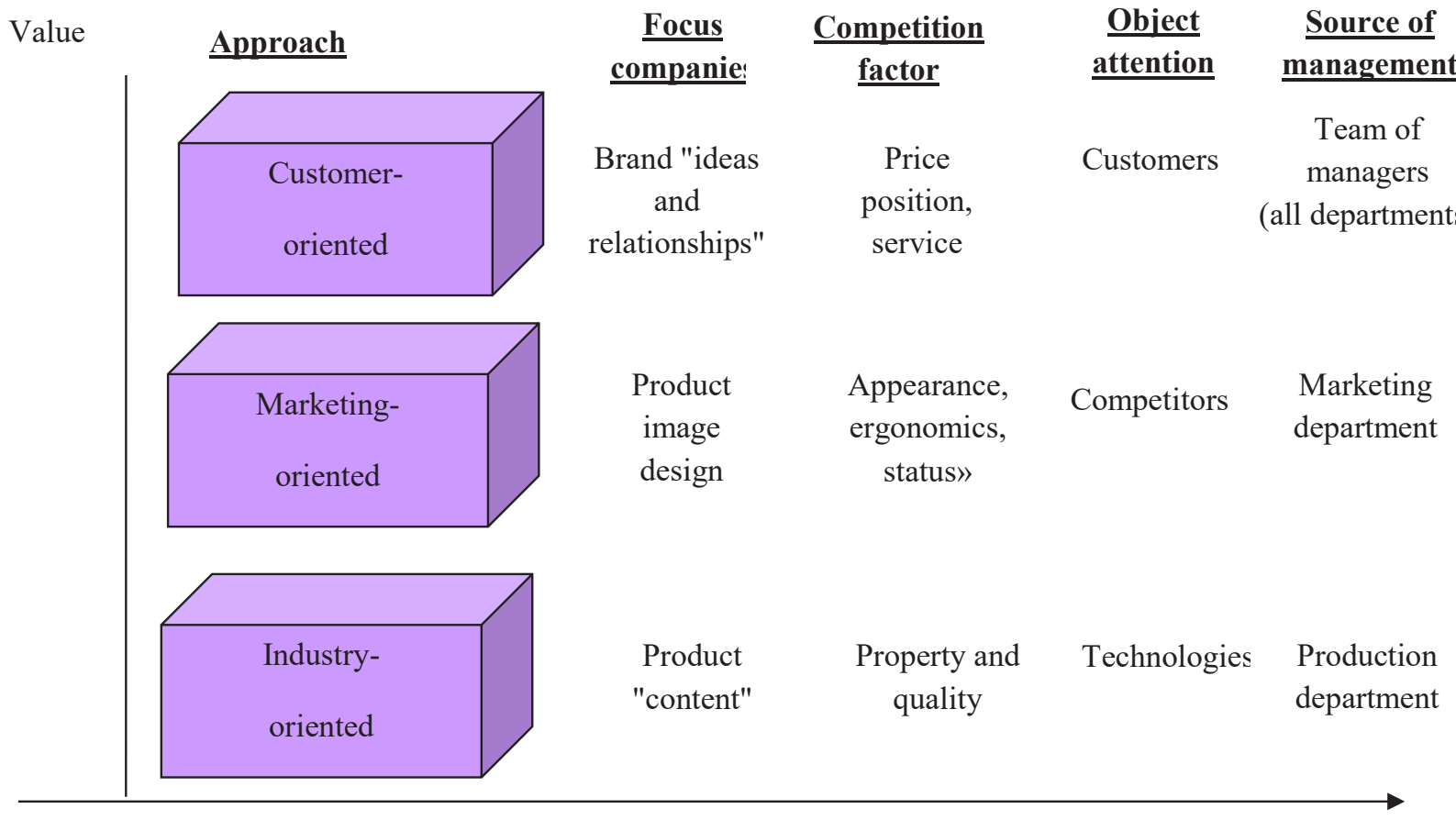

Time

Figure 1. The evolution of economic paradigms 
depending on the importance of the customer to the company and the stage at which their relationship.

Improving the manageability of the company, the coordinated interaction of all divisions of the company, the formation of a team - the customer chain of customer service, as a single business process, combines separate functional services.

To analyze the position of the organization and the level of its competitiveness in the market of tender procurement, it is first necessary to determine the intensity of interaction with customers by the formula:

$$
I=\sum_{i=1}^{N} \frac{Z}{n}
$$

where $Z$ - the number of projects, the discussion of the parameters of which and the assessment of their quality conducted by the customer in conjunction with the technologists of the organization;

$n$ - total number of orders.

Analysis of the sales structure made it possible to establish that the intensity of interaction with consumers is expressed in the frequency and amount of orders, products. Intensive interaction with consumers helps to form a loyal customer base, stable demand, specialize in a particular area of production.

It has been suggested that a positive change in one of these indicators has a direct positive impact on the other two; for example, strengthening interaction with suppliers increases competitiveness, and hence consumer loyalty. This interdependence of indicators allowed to determine the factors that characterize the competitiveness of the organization, interaction with suppliers and consumers, as they affect the strategic position of the organization in the market of tender procurement. However, the established interdependence does not solve the problem of defining strategic positions, and hence the problem of developing strategic alternatives. The problem is caused by the variability of the influence of these factors.

Due to the fact that the competitiveness of the organization and the overall efficiency of the tender procurement market is closely determined by how effectively it uses the latest technologies, the necessary factor determining the positioning of the organization in the market should be considered the level of technological equipment:

$$
K=\frac{O}{P},
$$

where $\mathrm{O}$ - is the number of technological innovations of the organization for the last year;

$P$ - total number of equipment.

Comparing the values of the criteria $I$ and $K$, it is possible to perform a preliminary assessment of the organization's capabilities in the tender procurement market, using the matrix shown in Figure 2.

Based on the matrix of evaluation of the capabilities of the organization, you can determine its position in terms of quadrants of the matrix:

I - the company has a significant advantage in the market of tender procurement, for the maintenance of which it is necessary to continue to maintain active feedback from consumers;

II - in the process of implementing the main stages of technology of interaction with the customer, the company needs to strengthen its position in the market by introducing the latest technologies and commissioning of new equipment.

III - the company should reconsider the direction of activity, to involve the corresponding park of the equipment under features of newly chosen specialization.

IV - high level of technological equipment of the organization allowed to reach the modern level of service quality. The company should carry out marketing activities aimed at attracting potential customers and implement the full range of technological stages of interaction with the customer.

The use of the presented matrix makes it possible to position the company in the market in the tender procurement market in accordance with the effectiveness of the customer-oriented approach.

Conclusions and suggestions. Creating a methodology to ensure the competitiveness of the organization in terms of tender procurement is a practical component of the customer-cantered approach, which aims to build individual relationships with each of the company's customers. The need to create such a technique is due to the fact that the "gross" approach to the analysis of sales dynamics and "ignoring" the dynamics of customer behaviour and preferences can lead the company to unsatisfactory results and, at least, already lead to lost profits.

The proposed method of ensuring the competitiveness of the organization in terms of tender procurement involves positioning the organization in the market of tender procurement. In turn, the positioning of the organization in the market of tender procurement will analyse the position of the organization and the level of its competitiveness. This became possible as a result of identifying the interdependence of indicators, allowed to determine the factors that characterize the competitiveness of the organization.

The scientific result of the study was the proposed method of making management decisions on the

Intensity of interaction with the customer

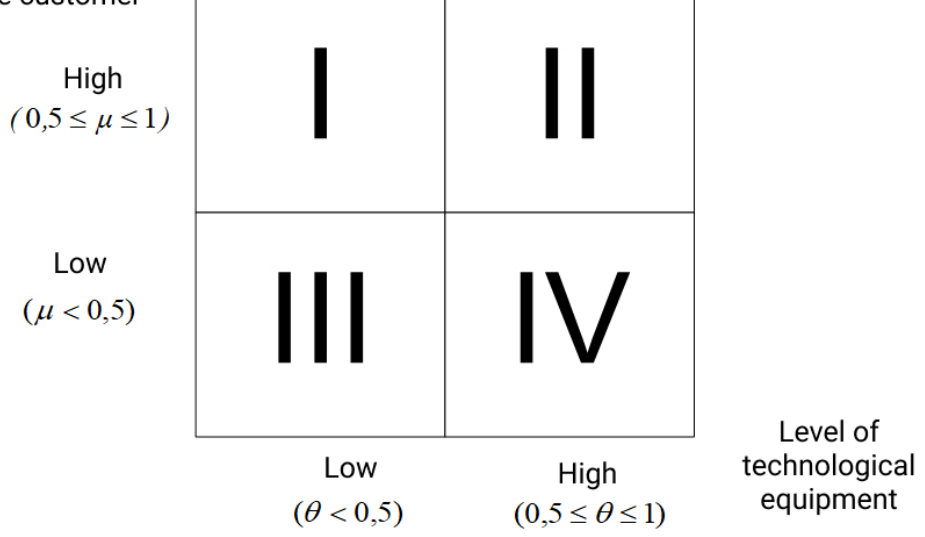

Figure 2. Matrix of preliminary assessment of the organization's capabilities in the tender procurement market 
organization of procurement of goods, works and services for units of the National Guard of Ukraine.

The practical result of the work is a set of recommendations to the management system of the enterprise regarding the organization of procurement of goods, works and services for units of the National Guard of Ukraine.

The direction of further research may be the creation of methods for assessing the effectiveness of the organization of procurement of goods, works and services.

\section{References:}

1. Naumenko M.O., Ryha O.S. (2018). Pidkhody do zabezpechennia stratehichnoho upravlinnia pidpryiemstv $v$ umovakh nestiikoho seredovyshcha [Approaches to ensuring strategic management of enterprises in an unstable environment]. Bulletin of Transport Economics and Industry (collection of scientific and practical articles), vol. 63, pp. 216-223.

2. Sokolovskyi S.A., Naumenko M.O. (2018). Analiz osoblyvostei upravlinnia informatsiinymy potokamy lohistychnykh protsesiv pidrozdiliv Natsionalnoi hvardii Ukrainy [Analysis of the peculiarities of information flow management of logistics processes of the National Guard of Ukraine]. Scientific Journal «ScienceRise», vol. 2, pp. 19-21.

3. Hrabovskyi Y., Yevsyeyev O. (2018). Development of methodological principles of supportpreservation engineering work. Technology audit and production reserves, vol. 2(2), pp. 43-49. doi: https://doi.org/10.1558 7/2312-8372.2018.127776

4. Wan X., Dresner M. (2015). Losing the Loop: An Empirical Analysis of the Dynamic Decisions Affecting Product Variety. Decision Sciences Journal, vol. 46(6), pp. 1141-1164.

5. Hrabovskyi Y., Fedorchenko V. (2019). Development of the optimization model of the interface of multimedia edition. EUREKA: Physics and Engineering, vol. 3, pp. 3-12. doi: 10.21303/2461-4262.2019.00902

6. Naumenko M., Hrabovskyi Y. (2018) Elaboration of methodology for designing a publishing and printing web portal. Eastern-European Journal of Enterprise Technologies, 2, 2(92), 14-22. doi: https://doi.org/10.155 87/1729-4061.2018.126305

7. Summary of the Methodology for assesing the Dynamics and Impacts of Electronic Commerce // OECD WPIE Ad Hoc Technucal Expert Group, 2004, p. 12.
8. Hrabovskyi Y., Brynza N, Vilkhivska O. (2020). Development of information visualization methods for use in multimedia applications. EUREKA: Physics and Engineering, vol. 1, pp. 3-17.

9. Naumenko M.O. (2018). Vdoskonalennia upravlinnia yakistiu produktsii vysokotekhnolohichnykh pidpryiemstv [Improving product quality management of high-tech enterprises]. Bulletin of Transport Economics and Industry (collection of scientific and practical articles), vol. 62, pp. 335-342.

\section{Бібліографрічний список:}

1. Науменко М.О., Рига О.С. Підходи до забезпечення стратегічного управління підприємств в умовах нестійкого середовища. Вісник економіки транспорту і промисловості (збірник науково-практичних статей) УДУЗТ. 2018. № 63. С. 216-223.

2. Соколовський С.А., Науменко М.О. Аналіз особливостей управління інформаційними потоками логістичних процесів підрозділів Національної гвардії України. Scientific Journal «ScienceRise». 2018. № 2. C. 19-21.

3. Hrabovskyi Y., Yevsyeyev O. Development of methodological principles of supportpreservation engineering work. Technology audit and production reserves. 2018. № 2(2). Pp. 43-49. doi: https://doi.org/10.15587/2312-8372.2018.127776

4. Wan X., Dresner M. Losing the Loop: An Empirical Analysis of the Dynamic Decisions Affecting Product Variety. Decision Sciences Journal. 2015. № 46(6). Pp. 1141-1164.

5. Hrabovskyi Y., Fedorchenko V. Development of the optimization model of the interface of multimedia edition. EUREKA: Physics and Engineering. 2019. № 3. Pp. 3-12. doi: $10.21303 / 2461-4262.2019 .00902$

6. Naumenko, M., Hrabovskyi, Y. (2018) Elaboration of methodology for designing a publishing and printing web portal. Eastern-European Journal of Enterprise Technologies, 2, 2(92), 14-22. doi: https://doi.org/10.15587/1729-4061.2018.126305

7. Summary of the Methodology for assesing the Dynamics and Impacts of Electronic Commerce // OECD WPIE Ad Hoc Technucal Expert Group. 2004. P. 12.

8. Hrabovskyi Y., Brynza N, Vilkhivska O. Development of information visualization methods for use in multimedia applications. EUREKA: Physics and Engineering. 2020. № 1. Pp. 3-17.

9. Науменко М.О. Вдосконалення управління якістю продукції високотехнологічних підприємств. Вісник економіки транспорту і промисловості (збірник науковопрактичних статей) УДАЗТ. 2018. Випуск № 62. C. $335-342$. 